Saudi Journal of Oral and Dental Research

Abbreviated Key Title: Saudi J Oral Dent Res

ISSN 2518-1300 (Print) |ISSN 2518-1297 (Online)

Scholars Middle East Publishers, Dubai, United Arab Emirates

Journal homepage: https://saudijournals.com

\title{
Is Mouth Self Examination (MSE) A Good Tool For Early Detection of Oral Cancer? A Review
}

\author{
RM Vatchala Rani ${ }^{1 *}$, BC Manjunath ${ }^{2}$, Manas Bajpai ${ }^{3}$, Pooja Gupta ${ }^{4}$, Akshay Bhargava ${ }^{5}$, Amit Kumar ${ }^{6}$ \\ ${ }^{1}$ Assistant Professor, Department of Oral Pathology and Microbiology, Faculty of Dentistry, Jamia Millia Islamia, Jamianagar, New \\ Delhi, India \\ ${ }^{2}$ Senior Professor and Head, Department of Public Health Dentistry, Postgraduate Institute of Dental Sciences, Rohtak, Haryana, India \\ ${ }^{3}$ Associate Professor, Department of Oral Pathology and Microbiology, NIMS Dental College, NIMS University, Jaipur, Rajasthan, \\ India. \\ ${ }^{4}$ Assistant Professor, Department of Oral Pathology and Microbiology, SR College of Dental Sciences, Faridabad, Haryana, India \\ ${ }^{5}$ Assistant Professor, Department of Oral Pathology and Microbiology Government Dental College, Jaipur, Rajasthan, India \\ ${ }^{6}$ Junior Resident, Department of Public Health Dentistry, Postgraduate Institute of Dental Sciences, Rohtak, Haryana, India
}

DOI: $\underline{10.36348 / \text { sjodr.2021.v06i04.005 }}$

| Received: 19.03.2021 | Accepted: 24.04.2021 | Published: 29.04.2021

*Corresponding author: RM Vatchala Rani

\section{Abstract}

Objectives: 1.To provide an overview of the effectiveness of mouth self examination (MSE) in early detection of oral cancer and oral potentially malignant lesions. Materials and Methods: Literature survey was carried out in March 2021 in electronic databases such as PubMed SCOPUS, EMBASE, COCHRANRE library, Science Direct using key words such as Mouth self examination, self mouth examination, oral cancer screening, etc... and a manual search was also done using the cross references and textbooks. Articles published in English language from 2000 to March 2021 which fulfilled the objectives of the study were included. The searches revealed 741 articles out of which 23 were selected after reading the full text articles. Results: The review of 23 articles revealed that mouth self examination (MSE) is one of the easiest and least expensive methods of identifying the lesions at the earliest stage by an individual where a specialist can be consulted if any suspicious lesions are found in the oral cavity. MSE has been advocated for early detection of oral cancers and can be very effective if performed by an individual accurately. MSE has low sensitivity. The sensitivity ranged from $8.6 \%$ to $43 \%$. MSE demonstrated high specificity when compared to sensitivity. The specificity of MSE ranged from $44 \%$ to $99 \%$. Conclusions: Mouth self examination is a good tool for identifying the suspicious lesions in the oral cavity and it can aid in early detection of oral cancer and oral potentially malignant disorders.

Keywords: Mouth self examination, Self mouth examination, sensitivity, toluedene blue.

Copyright () 2021 The Author(s): This is an open-access article distributed under the terms of the Creative Commons Attribution 4.0 International License (CC BY-NC 4.0) which permits unrestricted use, distribution, and reproduction in any medium for non-commercial use provided the original author and source are credited.

\section{INTRODUCTION}

Oral cancer is a major public problem in the world which is associated with increased mortality and morbidity [1]. The global incidence of lip, oral cavity, and pharyngeal cancers of 529,500 , corresponding to $3.8 \%$ of all cancer cases which is predicted to rise by $62 \%$ to 856,000 cases by 2035 because of changes in demographics. There is a wide geographical variation in the incidence of this cancer in the South East Asian region [2].

India has one of the highest incidences of oral cancers in the world constituting $60 \%$ of all the cancers cases. The high incidence of oral cancer and oral precancerous lesions in India has long been linked with the habit of betel quid chewing incorporating tobacco and smoking in innumerable forms. Oral cancer ranks number one among men and number three among women in India. Oral cancer constitutes $12 \%$ of all cancers in men and $8 \%$ of all cancers among women [3]. As high as 20 cases per 1 lakh population have been reported in India [3]. The incidence of oral cancer in India is 75,000 to 85,000 cases per year and resulting in deaths of around 60,000 annually, which is approximately one-fourth of global incidences of oral and pharyngeal cancer [4].

The increased mortality and morbidity associated with oral cancer is due to late diagnosis and unawareness. Since oral cancer is a painless lesion, 
often people report to health care facility at an advanced stage where survival rate becomes less [5]. The survival rate and prognosis increases if the tumor of the oral cavity is detected at the earliest stage. A surgical intervention followed by chemotherapy will increase the quality of life and decrease morbidity. Community based screening is one of the tool to identify oral cancers at the initial stages. The findings of a community based study has revealed that oral visual screening can reduce mortality in high-risk individuals and has the potential of preventing at least 37,000 oral cancer deaths worldwide [6].

Mass screening of oral cancer is not feasible because of increased manpower and cost. Hence it is essential to use alternative strategies which can detect oral cancers at earlier stage. Visual examination is usually employed in oral cancer screening. There is enough evidence in the literature to suggest that visual examination of oral cavity can detect oral cancers and potentially malignant lesions at the earliest stage which can reduce the mortality and morbidity associated with oral cancer. Various screening aids are used such as toluedene blue vital stain, brush biopsy, microlux DX, and velscope are often employed in oral cancer screening programs [7].

Oral cancer is associated with use of tobacco in various smoked and smokeless form. The individuals consuming tobacco form a high risk group for oral cancer. As mass screening is not feasible, a targeted approach that involve screening of high risk individuals with behavior modification of the lifestyles can reduce the incidence of oral cancer [8]. There are many types of screening such as high risk group screening where high risk individuals are screened for presence of oral pre-cancer and cancer. It can also be utilized for providing tobacco cessation intervention for enabling quit rates among tobacco consumers [9]. High risk group can be invited to visit a dentist where dentists perform complete oral examination to identify suspicious lesions and perform biopsy to conform the oral cancer diagnosis. This type of screening is referred as invitational screening. It has been reported that screening new cancers and OPMDs can be detected by invitational and opportunistic screening and offer a platform to raise the awareness and knowledge on this cancer [10]. Another form of screening called workplace screening can also be employed where high risk individuals working in industries and offices are screened for oral cancer using vital stains like toledene blue [11].

Since oral cavity is easily visible to an individual, any changes in the oral cavity can be found out by an individual through self mouth examination (SME). It is one of the easiest and least expensive methods of identifying the lesions at the earliest stage by an individual where a specialist can be consulted if any suspicious lesions are found in the oral cavity. Mouth self examination (MSE) has been advocated for early detection of oral cancers and can be very effective if performed by an individual accurately [12]. Moreover, many studies reported that most of the individuals have inability to perform MSE even after training giving evidence regarding the demerits associated with MSE [13-15]. Since there is lacuna in studies pertaining to mouth self examination, the present review was undertaken with an objective to find out the effectiveness of mouth self examination method in decreasing the mortality and morbidity associated with oral cancer.

\section{MATERIALS AND METHODS Search Strategy}

A literature survey was carried out in various electronic data bases in March 2021 to identify the articles required for this narrative review on mouth self examination. MeSH terms/keywords such as "mouth self examination and oral cancer" "self mouth examination and oral cancer" "self oral examination and oral cancer," "early detection of oral cancer," "oral cancer screening", "early detection aids of oral cancer" were used to search in the electronic data bases such as PubMed data base, SCOPUS, EMBASE, COCHRANRE library, Science Direct and a manual search was also done using the cross references and textbooks. Articles published in English language from 2000 to March 2021 which fulfilled the objectives of the study were included.

Article selection criteria: The articles required for the review was selected based on the inclusion and exclusion criteria. Quality assessment was also carried out to select the articles required for this review.

\section{Inclusion principles:}

1. Studies on characteristics and utility of mouth self examination in early detection of oral cancer

2. Studies on oral cancer screening

3. Studies on diagnostic aids of oral cancer

4. Descriptive studies, Clinical trials, randomized controlled studies, Investigative reports.

\section{Exclusion principles}

1. Animal based studies

2. Narrative reviews on mouth self examination

3. Studies which did not use mouth self examination

The searches revealed 741 articles out of which 123 were selected after reading the titles and abstracts. After reading the full text articles and applying the inclusion and exclusion criteria 23 articles were selected for the review which fulfilled the objectives of the study. 
RESULTS

Table-1: Effectiveness of self mouth examination in early detection of oral cancer

\begin{tabular}{|c|c|c|c|c|}
\hline $\begin{array}{l}\text { Authors } \\
\text { Name } \\
\text { and year }\end{array}$ & Participants & Interventions & Outcome & Inference \\
\hline $\begin{array}{l}\text { Ghani } \\
\text { WMN et. } \\
\text { al } 2019 \\
{[13]}\end{array}$ & $\begin{array}{l}\text { Indegenous } \\
\text { people in two } \\
\text { villages who had } \\
\text { the habit of } \\
\text { tobacco and } \\
\text { betel quid } \\
\text { chewing. }\end{array}$ & $\begin{array}{l}\text { Participants were } \\
\text { educated regarding oral } \\
\text { cancer were } \\
\text { demonstrated about } \\
\text { conducting MSE and } \\
\text { were asked to perform } \\
\text { the same and report } \\
\text { suspicious lesions. The } \\
\text { presences of lesions were } \\
\text { confirmed by a specialist. }\end{array}$ & $\begin{array}{l}\text { Many participants (64.5\%) } \\
\text { found MSE difficult to } \\
\text { perform and could not } \\
\text { visualize the oral cavity. } \\
\text { The prevalence of OPMDs } \\
\text { and oral mucosal lesions } \\
\text { was } 59 \% \text { and } 9 \% \\
\text { respectively. Sensitivity } \\
\text { and specificity of MSE for } \\
\text { detection of all types of } \\
\text { lesions were } 8.6 \% \text { and } \\
95.0 \% \text { respectively. }\end{array}$ & $\begin{array}{l}\text { MSE was not an effective self- } \\
\text { screening tool for early detection } \\
\text { of potentially malignant lesions } \\
\text { for this population. }\end{array}$ \\
\hline $\begin{array}{l}\text { Shah A et } \\
\text { al., } 2020 \\
{[14]}\end{array}$ & $\begin{array}{l}\text { A total of } 539 \\
\text { Buksa tribal } \\
\text { communities in } \\
\text { Dehradun } \\
\text { district, India. }\end{array}$ & $\begin{array}{l}\text { Participants were given } \\
\text { questionnaire, and were } \\
\text { taught to do MSE and } \\
\text { data was obtained by } \\
\text { interview method. }\end{array}$ & $\begin{array}{l}40.8 \% \text { practiced MSE and } \\
59.2 \% \text { have never } \\
\text { practiced MSE. MSE had } \\
\text { low sensitivity }(24.6 \%) \text {, } \\
\text { whereas high specificity } \\
(87.4 \%) \text { for all the lesions } \\
\text { and most sensitive in } \\
\text { detecting ulcers ( } 72.7 \%) \text {, } \\
\text { and highest specificity in } \\
\text { identifying red lesions } \\
(99.2 \%) \text {. }\end{array}$ & $\begin{array}{l}\text { Sensitivity of MSE for detecting } \\
\text { oral premalignant/malignant } \\
\text { lesions was low, specificity was } \\
\text { very high. }\end{array}$ \\
\hline $\begin{array}{l}\text { Jornet LP } \\
\text { et al., } \\
{[15]}\end{array}$ & $\begin{array}{l}\text { Eighty-six } \\
\text { patients ( } 37 \\
\text { females }[43.1 \%] \\
\text { and } 49 \text { males } \\
[56.9 \%]) \text { with a } \\
\text { mean age of } \\
58.60 \pm 10.7\end{array}$ & $\begin{array}{l}\text { Face-to-face sessions } \\
\text { were conducted for } 15 \\
\text { minutes among patients } \\
\text { in which training was } \\
\text { given regarding carrying } \\
\text { out oral self-examination. } \\
\text { Three months later, } \\
\text { patients were interviewed } \\
\text { by telephone and } \\
\text { enquired about } \\
\text { conduction of MSE. } \\
\text { Health belief model was } \\
\text { used in the study. }\end{array}$ & $\begin{array}{l}\text { Patients who felt } \\
\text { themselves subject to } \\
\text { susceptibility (OR: } 0.03 \\
95 \% \text { CI: } 0.0-0.86 ; \\
\text { p<0.04), severity (OR } 0.23 \\
95 \% 0.08-0.68 ; \mathrm{p}<0.008) \\
\text { and benefits (OR } 0.11 \\
95 \% 0.02-0.63 ; \mathrm{p}<0.013 \text { ) } \\
\text { were more likely to } \\
\text { perform self-examination. }\end{array}$ & $\begin{array}{l}\text { Training programmes in oral self- } \\
\text { examination are needed to } \\
\text { decrease morbidity and mortality } \\
\text { from oral cancer. }\end{array}$ \\
\hline $\begin{array}{l}\text { Furquim } \\
\text { CP et al., } \\
2014[16]\end{array}$ & $\begin{array}{l}\text { A total of } 44 \\
\text { patients with } \\
\text { Fanconi anemia } \\
\text { (FA), aged } \geq 18 \\
\text { years }\end{array}$ & $\begin{array}{l}\text { Patients were asked to } \\
\text { perform MSE, which was } \\
\text { evaluated using criteria } \\
\text { for mucosal visualization } \\
\text { and retracting ability. }\end{array}$ & $\begin{array}{l}\text { The sensitivity and } \\
\text { specificity values of MSE } \\
\text { were } 43 \% \text { and } 44 \% \text {, } \\
\text { respectively. The MSE } \\
\text { accuracy was } 43 \% \text {. Most } \\
\text { patients ( } 73 \% \text { ) reported } \\
\text { that MSE was easy or very } \\
\text { easy, although } 75 \% \\
\text { showed insufficient } \\
\text { performance. }\end{array}$ & $\begin{array}{l}\text { Mouth self examination is an } \\
\text { inexpensive technique which can } \\
\text { be used as a tool for early } \\
\text { detection of cancer in patients } \\
\text { with Fanconi anemia }\end{array}$ \\
\hline $\begin{array}{l}\text { Elango } \\
\text { KJ et al } \\
2011[17]\end{array}$ & $\begin{array}{l}34,766 \text { high risk } \\
\text { individuals } \\
\text { study } \\
\text { population. }\end{array}$ & $\begin{array}{l}\text { MSE brochures and } \\
\text { trained health workers } \\
\text { were employed for the } \\
\text { purpose of health } \\
\text { education and cancer } \\
\text { screening. }\end{array}$ & $\begin{array}{l}\text { MSE had a low sensitivity } \\
\text { of } 18 \% \text {, while the } \\
\text { specificity was } 99.9 \% \text {. }\end{array}$ & $\begin{array}{l}\text { MSE was instrumental in } \\
\text { identifying high-risk lesions such } \\
\text { as red patches }(66.7 \%) \text { and non- } \\
\text { healing ulcers }(42.9 \%) \text {, the } \\
\text { detection rate of white patches } \\
\text { was low }(12.7 \%) \text {. }\end{array}$ \\
\hline $\begin{array}{l}\text { Pivovor } \\
\text { A et al., } \\
2017[18]\end{array}$ & $\begin{array}{l}\text { A total of } 45 \\
\text { patients with } \\
\text { Fanconi } \\
\text { Anaemia, } 19\end{array}$ & $\begin{array}{l}\text { Self mouth examination } \\
\text { brochures were } \\
\text { distributed among } \\
\text { participants and parents. }\end{array}$ & $\begin{array}{l}\text { Performance evaluation } \\
\text { indicated that the } \\
\text { examination quality was } \\
\text { unsatisfactory in both }\end{array}$ & $\begin{array}{l}\text { Oral mucosa surveillance } \\
\text { performed by parents and } \\
\text { adolescents seems to be } \\
\text { inaccurate. However, as an oral }\end{array}$ \\
\hline
\end{tabular}


RM Vatchala Rani et al; Saudi J Oral Dent Res, Apr, 2021; 6(4): 160-165

\begin{tabular}{|c|c|c|c|c|}
\hline Authors & Participants & Interventions & Outcome & Inference \\
\hline & $\begin{array}{l}\text { children and } 26 \\
\text { adolescents } \\
\text { were study } \\
\text { participants }\end{array}$ & $\begin{array}{l}\text { Among children less than } \\
12 \text { years of age, } \\
\text { caregivers performed } \\
\text { MSE and adolescents } \\
\text { between } 12 \text { and } 16 \text { years } \\
\text { of age performed MSE } \\
\text { themselves. }\end{array}$ & groups. & $\begin{array}{l}\text { examination is a relatively } \\
\text { inexpensive form of secondary } \\
\text { prevention, it merits attention to } \\
\text { teaching the technique to patients } \\
\text { with FA and their caregivers. }\end{array}$ \\
\hline $\begin{array}{l}\text { Lee } \mathrm{H} \text { et } \\
\text { al., } 2019 \\
{[19]}\end{array}$ & $\begin{array}{l}\text { The participants } \\
\text { were randomly } \\
\text { assigned to } \\
\text { intervention (IG; } \\
\mathrm{n}=171) \text { and } \\
\text { control groups } \\
(\mathrm{CG} ; \mathrm{n}=176) \text {. }\end{array}$ & $\begin{array}{l}\text { In the IG, participants } \\
\text { received a three-chapter } \\
\text { one-on-one teaching } \\
\text { course from Layman } \\
\text { Health Advisory, } \\
\text { whereas those in the CG } \\
\text { received only a leaflet. }\end{array}$ & $\begin{array}{l}\text { The IG participants were } \\
2.04 \text { times more likely to } \\
\text { conduct a monthly MSE } \\
\text { than those in the CG }(95 \% \\
\text { confidence interval: } 1.31 \text { - } \\
\text { 3.17) and showed } \\
\text { significantly higher self- } \\
\text { efficacy levels toward } \\
\text { OSC and MSE ( } \beta=0.53 \\
\text { and } 0.44, \text { effect size }= \\
0.33 \text { and } 0.25 \text {, } \\
\text { respectively) and a lower } \\
\text { barrier level for OSC }(\beta= \\
-1.81, \text { effect size }=-0.24) \text {. }\end{array}$ & $\begin{array}{l}\text { The Layman Health Advisory } \\
\text { intervention had a significantly } \\
\text { positive effect on MSE, } \\
\text { strengthening self-efficacy and } \\
\text { reducing barriers to OCS among } \\
\text { aboriginal populations. }\end{array}$ \\
\hline $\begin{array}{l}\text { Scott SE } \\
2010 \text { [20] }\end{array}$ & $\begin{array}{l}\text { Participants } \\
\text { were } 53 \text { smokers } \\
\text { aged over } 45 \\
\text { years. }\end{array}$ & $\begin{array}{l}\text { Participants received an } \\
\text { oral mucosal examination } \\
\text { by the dentist and then } \\
\text { performed MSE after } \\
\text { education through a self- } \\
\text { read leaflet. The dentist } \\
\text { and participant both } \\
\text { recorded the presence } \\
\text { and absence of } \\
\text { potentially malignant oral } \\
\text { lesions. }\end{array}$ & $\begin{array}{l}\text { The prevalence of } \\
\text { potentially malignant oral } \\
\text { lesions was } 22 \% \text {. The } \\
\text { sensitivity of MSE was } \\
33 \% \text { and the specificity } \\
\text { was } 54 \% \text {. MSE had a } \\
\text { positive predictive value } \\
\text { of } 17 \% \text { and a negative } \\
\text { predictive value of } 73 \% \text {. }\end{array}$ & $\begin{array}{l}\text { The high risk group were poor at } \\
\text { correctly identifying the presence } \\
\text { or absence of potentially } \\
\text { malignant oral lesions. A leaflet } \\
\text { may be an ineffective training } \\
\text { tool to aid self-identification of } \\
\text { potentially malignant oral } \\
\text { lesions. }\end{array}$ \\
\hline
\end{tabular}

\section{RESULTS}

\section{Mouth Self Examination Procedure}

The population or high risk individuals are either demonstrated or provided a pictorial booklet regarding conduction of mouth self examination. Many studies have reported regarding educating high risk individuals through videos. The individual is advised to stand in front of the mirror or hold a hand held mirror and observe the lips and commissure to detect any abnormalities. Then he is advised to lift the upper lip, lower lip and visualize in the mirror to detect any abnormalities in the labial mucosa. Smokeless tobacco chewers usually keep the tobacco quid in the lower labia mucosa. Usually a tobacco pouch keratosis is seen in this area. Then the individual is advised to pull the cheek to expose the buccal mucosa. Most of the lesions are seen in the buccal mucosa. Oral potentially malignant disorders (OPMDs) like leukoplakia, erythroplakia and oral submucous fibrosis are usually seen. Oral cancer of the buccal mucosa is also very common in India. Then individual is advised to take a cloth and pull the tongue outside and see the lateral borders of the tongue. Cancer of the tongue is most common cancers and is associated with high mortality. Then patient is advised to open the mouth widely and visualize the palate. A change in the palate such as smoker's palate is observed. High risk individuals are trained to identify suspicious lesions in the oral cavity and report to the health care centre where it will be diagnosed by specialist. When suspicious lesions are diagnosed as oral cancer, then immediate surgical intervention will decrease the morbidity and mortality associated with oral cancer [21].

Mouth self examination (MSE) for detection of oral cancer and breast self examination (BSE) for detection of breast cancer should be promoted for early detection of cancers as it is economical and cost effective [22]. As both oral cavity and breasts can be visualized by an individual, MSE and BSE has been reported to be effective in identifying cancers at the earliest stage.

\section{Diagnostic efficacy of mouth self examination (MSE)}

Mouth self examination is a tool where an individual identifies a suspicious lesions which may be perceived as oral cancer or oral potentially malignant disorders but only confirmed by a specialist by visual examination and biopsy. Hence MSE can be considered as a diagnostic tool. Sensitivity and specificity may be 
RM Vatchala Rani et al; Saudi J Oral Dent Res, Apr, 2021; 6(4): 160-165

applied to MSE. Sensitivity measures how often a test correctly identifies a positive result for people who have the condition that's being tested for which is also referred as true positive. A test that's highly sensitive will identify almost everyone who has the disease and not differentiate false-negative results [23]. As reported by many studies, MSE has low sensitivity. The sensitivity ranged from $8.6 \%$ to $43 \%$. The low sensitivity was due to inability to perform an adequate MSE where red and white lesions are identified. Since an individual has to visualize in the mirror, the lesions are always missed as some areas of the oral cavity is difficult to view in the mirror. Specificity of a test can be defined as the ability of a screening test to detect a true negative, being based on the true negative rate, correctly identifying people who do not have a disease. MSE demonstrated high specificity when compared to sensitivity. The specificity of MSE ranged from $44 \%$ to $99 \%$.

\section{Advantages}

1. MSE is easy to perform and economical.

2. It can be used for early detection of oral cancer and potentially malignant lesions.

3. It helps in creating awareness about oral cancer.

4. It helps in monitoring the changes in the oral cavity.

5. It can be used in motivation of an individual to quit tobacco habits.

6. It has high levels of specificity.

7. May decrease the mortality and morbidity associated with oral cancer [13-16].

\section{Disadvantages}

1. Difficult to make a person understand the technique of conducting MSE.

2. Do not always report to health care centre if lesions are detected upon MSE.

3. Only live demonstration with application of health belief model is successful.

4. Leaflets and pamphlets are not effective as person cannot understand the procedure of MSE.

5. Has low sensitivity [17-19].

\section{DISCUSSION}

Oral cancer has become a major challenge throughout the world because of it poor prognosis. The five year survival rate is less than $50 \%$ even in the modern era despite availability of advanced treatment modalities which makes it necessary to decrease the incidence of oral cancer [24]. The major reason for poor survival rate is due to metastasis and development of cancers in different parts of the body as well as recurrence of primary oral cancer. The only way to control the incidence of oral cancer is to control the risk factors such as tobacco and alcohol. Despite many regulatory efforts and health education approaches the consumption of tobacco has not decreased. Hence there is increased incidence of oral cancer in the world particularly in South East Asian countries like India,
Pakistan, Bangladesh, Malaysia, Indonesia and Phillipines [25].

Since screening for oral cancer of the entire population is not feasible, other modalities has been employed and use of mouth self examination is one tool which has been studied for its utility in decreasing the mortality and morbidity of oral cancer. MSE has not been studied extensively and hence there are very few studies conducted to assess its utility. None of the studies reported decease in the mortality as many studies were cross sectional in nature and require prospective studies to get more evidence. Nevertheless, mouth self examination can be advocated for patient education and motivation for oral cancer awareness. It can also enhance quit rates if tobacco cessation intervention is carried out. MSE has low sensitivity and high specificity rates which are not often considered a valid diagnostic tool [13-19]. MSE technique can be demonstrated during community programs where live demonstration of the procedure can be given. It can also be used during opportunistic screening in dental clinics, invitational screening and workplace screening [11].

\section{CONCLUSIONS}

Mouth self examination is a good tool for identifying the suspicious lesions in the oral cavity and it can aid in early detection of oral cancer and potentially malignant lesions. Prospective studies are required to provide more evidence regarding decrease in the mortality associated with oral cancer.

\section{REFERENCES}

1. Van der Waal, I. (2013). Are we able to reduce the mortality and morbidity of oral cancer; some considerations. Medicina oral, patologia oral y cirugia bucal, 18(1), e33-37.

2. Shield, K. D., Ferlay, J., Jemal, A., Sankaranarayanan, R., Chaturvedi, A. K., Bray, F., \& Soerjomataram, I. (2017). The global incidence of lip, oral cavity, and pharyngeal cancers by subsite in 2012. CA: a cancer journal for clinicians, 67(1), 51-64.

3. Coelho, K. R. (2012). Challenges of the oral cancer burden in India. Journal of cancer epidemiology, 2012:701932.

4. Shrestha, A. D., Vedsted, P., Kallestrup, P., \& Neupane, D. (2020). Prevalence and incidence of oral cancer in low- and middle- income countries: A scoping review. European journal of cancer care, 29(2), e13207.

5. Rutkowska, M., Hnitecka, S., Nahajowski, M., Dominiak, M., \& Gerber, H. (2020). Oral cancer: The first symptoms and reasons for delaying correct diagnosis and appropriate treatment. Advances in Clinical and Experimental Medicine, 29(6), 735-743.

6. Sankaranarayanan, R., Ramadas, K., Thomas, G., Muwonge, R., Thara, S., Mathew, B., ... \& 
RM Vatchala Rani et al; Saudi J Oral Dent Res, Apr, 2021; 6(4): 160-165

Trivandrum Oral Cancer Screening Study Group. (2005). Effect of screening on oral cancer mortality in Kerala, India: a cluster-randomised controlled trial. The Lancet, 365(9475), 1927-1933.

7. Jitender, S., Sarika, G., Varada, H. R., Omprakash, Y., \& Mohsin, K. (2016). Screening for oral cancer. J Exp Ther Oncol. 11(4), 303-307.

8. Nagao, T., \& Warnakulasuriya, S. (2020). Screening for oral cancer: Future prospects, research and policy development for Asia. Oral oncology, 105, 104632.

9. Lalli, A., Aldehlawi, H., Buchanan, J. A. G., Seoudi, N., Fortune, F., \& Waseem, A. (2021). Screening for oral cancer utilising risk-factor analysis is ineffective in high-risk populations. British Journal of Oral and Maxillofacial Surgery, 59(1), e17-e22.

10. Monteiro, L. S., Salazar, F., Pacheco, J. J., Martins, M., \& Warnakulasuriya, S. (2015). Outcomes of invitational and opportunistic oral cancer screening initiatives in $\mathrm{O}$ porto, $\mathrm{P}$ ortugal. Journal of Oral Pathology \& Medicine, 44(2), 145-152.

11. Uplap, P. A., Mishra, G. A., Majumdar, P., Gupta, S. D., Rane, P. S., Sadalge, P. K., ... \& Shastri, S. S. (2011). Oral Cancer Screening at Workplace in India-One-year Follow-up. Indian journal of community medicine: official publication of Indian Association of Preventive \& Social Medicine, 36(2), 133-138.

12. Shrestha, G., \& Maharjan, L. (2020). Mouth Selfexamination for Prevention and Control of Oral Cavity Cancer. JNMA: Journal of the Nepal Medical Association, 58(225), 360-362.

13. Ghani, W. M. N., Razak, I. A., Doss, J. G., Ramanathan, A., Tahir, Z., Ridzuan, N. A., ... \& Zain, R. B. (2019). Mouth self- examination as a screening tool for oral potentially malignant disorders among a high- risk Indigenous population. Journal of public health dentistry, 79(3), 222-230.

14. Shah, A., Bhushan, B., Akhtar, S., Singh, P. K., Garg, M., \& Gupta, M. (2020). Effectiveness of mouth self-examination for screening of oral premalignant/malignant diseases in tribal population of Dehradun district. Journal of Family Medicine and Primary Care, 9(8), 4381-4385.

15. Jornet, P. L., Garcia, F. G., Berdugo, M. L., Perez, F. P., \& Lopez, A. P. F. (2015). Mouth selfexamination in a population at risk of oral cancer. Australian dental journal, 60(1), 59-64.
16. Furquim, C. P., Pivovar, A., Cavalcanti, L. G., Araújo, R. F., Bonfim, C. M. S., \& Torres-Pereira, C. C. (2014). Mouth self-examination as a screening tool for oral cancer in a high-risk group of patients with Fanconi anemia. Oral surgery, oral medicine, oral pathology and oral radiology, 118(4), 440-446.

17. Elango, K. J., Anandkrishnan, N., Suresh, A., Iyer, S. K., RamaIyer, S. K., \& Kuriakose, M. A. (2011). Mouth self-examination to improve oral cancer awareness and early detection in a high-risk population. Oral Oncology, 47(7), 620-624.

18. Pivovar, A., Furquim, C. P., Bonfim, C., \& Torres- Pereira, C. C. (2017). Mouth examination performance by children's parents and by adolescents in Fanconi anemia. Pediatric blood \& cancer, 64(11), e26622.

19. Lee, H., Ho, P. S., Wang, W. C., Hu, C. Y., Lee, C. H., \& Huang, H. L. (2019). Effectiveness of a health belief model intervention using a lay health advisor strategy on mouth self-examination and cancer screening in remote aboriginal communities: A randomized controlled trial. Patient education and counseling, 102(12), 2263-2269.

20. Scott, S. E., Rizvi, K., Grunfeld, E. A., \& McGurk, M. (2010). Pilot study to estimate the accuracy of mouth self- examination in an at- risk group. Head \& neck, 32(10), 1393-1401.

21. MacCarthy, D., Flint, S. R., Healy, C., \& Stassen, L. F. (2011). Oral and neck examination for early detection of oral cancer-a practical guide. J Ir Dent Assoc, 57(4), 195-199.

22. Coleman, C. (2017, May). Early detection and screening for breast cancer. In Seminars in oncology nursing (Vol. 33, No. 2, pp. 141-155). WB Saunders.

23. Eusebi, P. (2013). Diagnostic accuracy measures. Cerebrovascular Diseases, 36(4), $267-$ 272.

24. Ghani, W. M. N., Ramanathan, A., Prime, S. S., Yang, Y. H., Razak, I. A., Abdul Rahman, Z. A., ... \& Zain, R. B. (2019). Survival of oral cancer patients in different ethnicities. Cancer investigation, 37(7), 275-287.

25. Rao, S. V. K., Mejia, G., Roberts-Thomson, K., \& Logan, R. (2013). Epidemiology of oral cancer in Asia in the past decade-an update (20002012). Asian Pacific journal of cancer prevention, 14(10), 5567-5577. 